www.jmscr.igmpublication.org Impact Factor 5.244

Index Copernicus Value: 5.88 ISSN (e)-2347-176x ISSN (p) 2455-0450 crossref DOI:_http://dx.doi.org/10.18535/jmscr/v4i6.43

Journal Of Medical Science And Clinical Research

\title{
Correlation of Neuron-Glial Antigen 2 (NG2) Expression to MLL Gene Rearrangements in Acute Lymphoblastic Leukemia
}

\author{
Authors \\ Hanaa Mohamed Afifi ${ }^{1}$, Gehan Mostafa Hamed ${ }^{2}$, Esraa Maonsour Shehata ${ }^{3}$ \\ ${ }^{1}$ MD Clinical Pathology, Professor of Clinical Pathology, Clinical Pathology Department, Hematology Unit, \\ Faculty of Medicine, Ain Shams University, Cairo, Egypt \\ ${ }^{2}$ MD Clinical Pathology, Lecturer of Clinical Pathology, Clinical Pathology Department, Hematology Unit, \\ Faculty of Medicine, Ain Shams University, Cairo, Egypt \\ ${ }^{3}$ Msc Clinical Pathology, Clinical Pathology Department, Hematology Unit, Faculty of Medicine, Ain \\ Shams University, Cairo, Egypt \\ Corresponding Author/Reprint \\ Gehan Mostafa Hamed
}

67 El Nasr St, Sheraton Heliopolis, Cairo, Egypt

Email: gehanzeina@yahoo.com Mobile no: 0020201224954542

\begin{abstract}
Background: Acute lymphoblastic leukemias (ALL) carrying a chromosomal translocation involving the mixed-lineage leukemia gene (MLL) has a particularly poor prognosis. The presence of the MLL translocation often results in an early relapse after chemotherapy. For this reason, the accurate detection of $M L L$ rearrangements $(M L L-r)$ is crucial when dealing with this aggressive type of leukemia. We determined the correlation of the surface antigen neuron-glial antigen 2 (NG2) to the presence of MLL-r, and its value as a rapid inexpensive method for prediction of MLL-r at diagnosis of ALL patients.

Methods: 44 newly diagnosed children with ALL were studied for the presence of MLL rearrangement by fluorescence in situ hybridization (FISH), as well as measurement of NG2 expression by flow cytomery.

Results: MLL-r was successfully detected in 16 (36.4\%) patients, while NG2 expression was positive in 14 $(31.8 \%)$ patients. A positive correlation was found between $N G 2$ expression and $M L L-r(r=0.531, p<0.001)$, receiver operating characteristic curve (ROC) analysis revealed that $N G 2$ value $\geq 18.6 \%$ could predict the presence of MLL-r with $85 \%$ sensitivity, 95\% specificity, and 90\% accuracy $(p=0.004)$. Hyperleucocytosis, high lactate dehydrogenase (LDH) level, and presence of central nervous system (CNS) infiltration were significantly higher in patients with MLL-r and positive NG2 expression compared with MLL-r negative and NG2 negative ALL patients ( $p<0.001$ ).

In conclusion, immunophenotypic analysis of NG2 expression with a cutoff value $\geq 18.6 \%$ allows the identification and prediction of MLL-r, with high specificity and accuracy suggesting that flow cytometry is a reliable, cost-effective and rapid tool for detection of $M L L-r$.
\end{abstract}

Keywords: ALL, NG2 expression, MLL rearrangements. 


\section{Introduction}

B-lymphoblastic leukemia (B-ALL) is the most common malignancy of childhood and a disease with a poor prognosis among adults [1] Cytogenetic analysis of leukemic cells is the cornerstone for the prognostic stratification of ALL patients at the onset of disease being an independent factor in predicting clinical outcome and determining the duration and type of treatment ${ }^{[2]}$. Aberrations of chromosome 11q23 result in rearrangements of the mixed lineage leukemia (MLL) gene, a gene involved in the regulation of hemopoetic cell differentiation. Such aberrations occur in about $5-10 \%$ of acute lymphoid leukemia and in 5\% of AML cases and are associated with a poor prognosis ${ }^{[3]}$. For this reason, the accurate detection of MLL rearrangements (MLL-r) is crucial when dealing with this aggressive type of leukemia.

Current diagnostic techniques of MLL-r are either time-consuming and may be not able to detect all genetic abnormalities (cryptic) involving MLL gene as karyotyping, or are costly, requires specialized skills, and not always available at initial diagnosis such as fluorescence in situ hybridization (FISH) and reverse transcriptase polymerase chain reaction (RT-PCR) ${ }^{[4,5]}$. Because the early identification of MLL rearrangements may guide therapy or clinical trial enrollment $[6,7,8]$, it would be useful to have a more efficient, rapid screening, and cost effective technique to identify MLL-r at diagnosis .

With the discovery in humans of a homolog of the cell surface chondroitin sulfate proteoglycan neuron-glial antigen 2 (NG2) molecule in rats, previous groups have reported that MLL-r may be predicted through the cell surface recognition of NG2 using the monoclonal antibody (MoAb) 7.1 ${ }^{[9-12]}$. The mechanisms underlying this association are still being examined ${ }^{[13,14]}$ and a lack of association has been reported in certain cases ${ }^{[15]}$. This study aims to determine the association of expression of the surface antigen NG2 with the presence of MLL-r, and its value as a rapid inexpensive method for prediction of MLL-r at diagnosis of ALL patients.

\section{Subjects and methods}

This cross-sectional study was carried out on 44 newly diagnosed childhood ALL included, eight male infants and 36 children (male to female ratio $1: 1$ ), who were attending the Hematology/Oncology Unit, in the Pediatric Hospital, Ain Shams University. An informed consent was obtained from the legal guardians of each patient before enrollment. This study was approved by the ethical committee of Ain Shams University.

All the patients were subjected to full clinical history taking, laying stress on the presence of leukemia associated symptoms (fever, pallor, bleeding tendency, and bone aches). Thorough clinical examination was performed laying stress on the presence of lymphadenopathy, splenomegaly and hepatomegaly. Diagnostic workup for acute leukemia included complete blood counts (CBC) using Coulter LH 750 cell counter (Coulter, Electronics, Hialeah, FL, USA), and bone marrow (BM) aspiration, with examination of Leishman stained peripheral blood (PB) and BM smears. Flow cytometric immunophenotyping was performed using a standard panel of monoclonal antibodies (MoAb) using Coulter Epics XL 3-color flow cytometer (Coulter, Electronics, Hialeah, FL, USA). Chromosome 11q23 break apart was detected by fluorescence in situ hybridization (FISH). Diagnosis of ALL was established in all cases on the basis of clinical, morphologic, immunophenotypic, cytogenetic analysis, according to the WHO classification ${ }^{[16]}$.

\section{Sampling}

Blood and BM aspiration samples were collected under complete aseptic conditions on ethylene diamine tetra-acetic acid, potassium salt $\left(\mathrm{K}_{2}{ }^{-}\right.$ EDTA) $(1.2 \mathrm{mg} / \mathrm{mL})$ for CBC and flow cytometry. For FISH examination $1 \mathrm{~mL}$ of $\mathrm{BM}$ aspirate was 
collected in vacutainer tubes coated with lithium heparin.

\section{NG2 expression}

Fifty microliters of each sample were incubated with $5 \mu \mathrm{L}$ of NG2-PE conjugated monoclonal antibody (7.1 clone) supplied by IMMUNOTECH SAS (Beckman Coulter Company, Marseille, France), or its isotypic control for 15 minutes at room temperature in the dark. Then the cells were washed with $2 \mathrm{~mL}$ phosphate buffered saline, followed by red cell lysis using $1.5 \mathrm{~mL}$ of lysing solution $\left(\mathrm{NH}_{4} \mathrm{Cl}\right.$ buffered with $\mathrm{KHCO}_{3}$ at $\mathrm{pH}$ 7.2) for 3 minutes at room temperature in the dark. After appropriate gating of lymphoblasts, surface NG2 expression was determined. Data acquisition and analysis were performed on Epics XL flow cytometer (Coulter Corporation, Hialeah, FL, USA) using SYSTEM II version 3 software (Beckman Coulter, USA) with a standard 3-color filter configuration.

\section{Cytogenetic analysis}

Cytogenetic analysis was performed by FISH technique using fluorophore labeled locus specific identifier (LSI) MLL dual colour, break-apart rearrangement probe (Vysis, Abbot, molecular diagnostics, USA). Slides were prepared from material fixed in methanol-acetic acid ${ }^{[17]}$. Hybridization and detection of hybridization signals were performed according to the manufacturer's protocols. At least 100 interphase cells were evaluated using the Chromoscan CytoVision7.3.1 (Leica Biosystem, Richmond Inc., USA) in order to detect the target abnormalities. Images of FISH were captured through the program Mac Probe 4.4 of Power Gene System (Applied Imaging Corporation, USA). The presence of co-localized orange and green (yellow) signal represents normal MLL gene, whereas, separated orange and green signals indicates MLL break-apart.

\section{Statistical analysis}

Data were analyzed using statistical program for Social Science (SPSS) version 18 IBM compatible PC. Quantitative data were described in the form of number and percentage, range, mean \pm standard deviation (SD). Qualitative data were described as frequency, and percentage. Student $t$, MannWhitney $U$, Chi square $x^{2}$ were used for intergroup comparison. Pearson's correlation was used to assess the association between two normally distributed variables and Spearman's rank correlation coefficient was used for correlating between data when one or more is skewed. Receiver operating characteristic (ROC) curve was used to find out the overall diagnostic value of NG2 and to determine the best cut-off value with detection of sensitivity and specificity at this cut-off value. A $p$ value $<0.05$ was considered significant.

\section{Results}

Clinical and laboratory data are shown in Table 1. According to the results of flow cytometric phenotyping, the 44 studied cases were diagnosed as precursor B-ALL, the surface marker NG2 was positive in 14 (31.8\%) of studied patients.

FISH analysis using LSI MLL dual color, breakapart rearrangement probe for detection of MLL gene rearrangements was successfully performed on the $44 \mathrm{BM}$ samples revealing negative MLL-r (two yellow signals) in $28(63.6 \%)$ patients (figure 1A), positive MLL-r (one yellow, one orange and one green signals) in $16(36.4 \%)$ patients including $6(37.5 \%)$ infants and $10(62.5 \%)$ children (figure 1B), and one case showed three yellow signals (figure 1C). 
$[\mathrm{A}]$

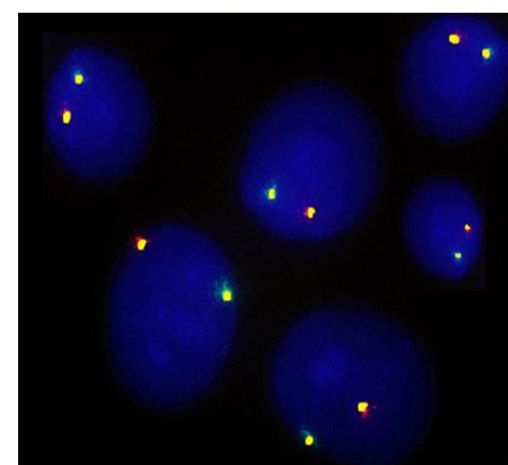

[B]

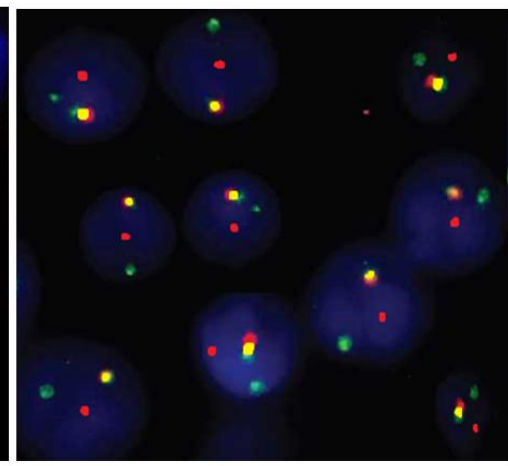

[C]

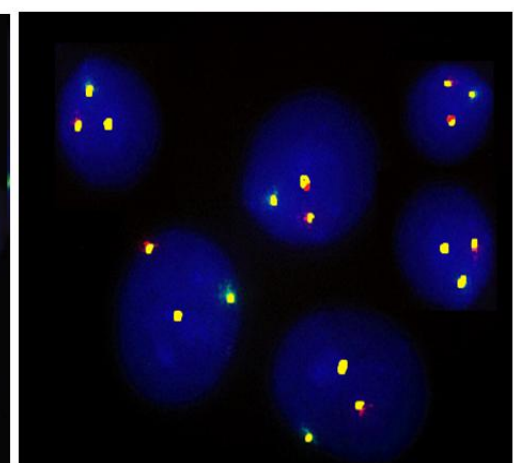

Figure 1. FISH analysis with the dual-colour LSI-MLL gene break apart probe (Vysis) revealing [A] two yellow signals indicating negative MLL gene rearrangement [B] one yelow, one orange and one green signals indicating presence of MLL gene rearrangement $[\mathrm{C}]$ three yellow signals indicating the presence of three MLL copies but no MLL rearrangement.

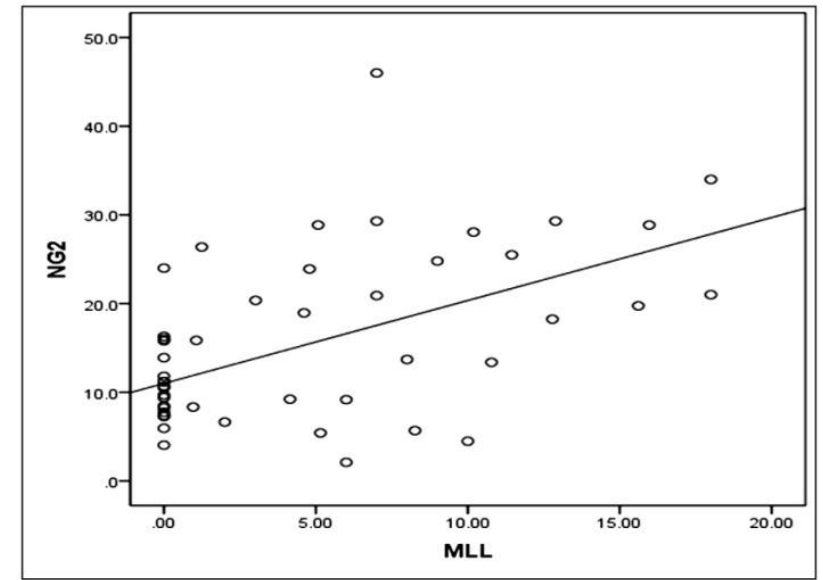

Figure 2. Correlation between NG2 expression and MLL gene rearrangement in the studied ALL patients.

Comparison between ALL patients with positive and negative MLL gene rearrangement:

As shown in Table 2, comparison between MLL-r positive and negative patients revealed a significant difference between the two groups as regards the incidence of central nervous system (CNS) infiltration $(\mathrm{p}=0.005)$ while, no significant difference was found as regards their age, sex, or the presence of hepatomegaly, splenomegaly and lymphadenopathy ( $p>0.05)$.

With respect to laboratory data, the MLL-r positive group showed a significantly higher lactate dehydrogenase $(\mathrm{LDH})$ level $(\mathrm{p}<0.001)$ and white blood cells count (WBC) $(\mathrm{p}<0.001)$. No significant difference was detected as regards their hemoglobin level $(\mathrm{p}=0.110)$, platelets count ( $\mathrm{p}=0.111)$, PB blasts $(\mathrm{p}=0.399)$ or BM blasts $(p=0.156)$. Moreover, the percentage of NG2 positivity and mean NG2 \% expression were significantly higher in patients with positive MLL-r compared with negative ones $(p<0.001)$.

Comparison between ALL patients with positive and negative NG2 expression:

Comparison between NG2 positive and negative ALL patients revealed significant difference as regards the presence of CNS infiltration $(\mathrm{P}=0.002), \quad$ hepatomegaly $\quad(\mathrm{p}=0.002), \quad$ and splenomegaly $(\mathrm{p}=0.014)$. NG2 positive group also showed higher median WBC $(<0.001)$, mean NG2 $\%$ expression $(\mathrm{p}<0.001)$, as well as, the percentage of positive MLL-r patients ( $\mathrm{p}<0.001)$ (Table 2).

Correlation between NG2 expression and MLL gene rearrangement in the studied ALL patients:

As shown in Figure 2, NG2 expression was positively correlated with MLL gene rearrangement $(\mathrm{r}=0.53, \mathrm{p}<0.001)$. Noteworthy, one studied NG2 positive case showed three yellow signals indicating the presence of three copies of MLL but no rearrangement was observed, amplification of MLL could be either due to trisomy of chromosome 11 or the presence of partial tandem duplication of MLL gene (MLLPTD).

ROC curve analysis was used to detect the cut off value of NG2 \% expression that could predict the presence of 11q23 break-apart (MLL gene rearrangement). It revealed that $\mathrm{NG} 2$ level $\geq$ 
$18.6 \%$ is a significant predictor of the presence of MLL-r (area under the curve [AUC] 0.84, confidence interval [CI] $0.63-1$ ) with $85 \%$ sensitivity, 95\% specificity and 90\% accuracy $(\mathrm{p}=0.004)$.

Table 1. Descriptive data of the studied patients with acute lymphoblastic leukemia

\begin{tabular}{|c|c|}
\hline Variable & $\operatorname{ALL}(n=44)$ \\
\hline Age (years), median (IQR) & $3.5(2-7.5)$ \\
\hline Infants, n (\%) & $8(18.2)$ \\
\hline Children, n (\%) & $36(81.8)$ \\
\hline Males, n (\%) & $26(59.1)$ \\
\hline Hepatomegaly, n (\%) & $30(68.2)$ \\
\hline Splenomegaly, n (\%) & $34(77.3)$ \\
\hline Lymphadenopathy, n (\%) & $34(77.3)$ \\
\hline CNS infiltration, $\mathrm{n}(\%)$ & $4(9.1)$ \\
\hline $\mathrm{WBC}\left(\mathrm{X} 10^{9} / \mathrm{L}\right)$, mean $\pm \mathrm{SD}$ & $16.1(10.2-64.6)$ \\
\hline Hemoglobin $(\mathrm{gm} / \mathrm{dL})$, mean \pm SD & $6.97 \pm 1.5$ \\
\hline Platelets $\left(\times 10^{9} / \mathrm{L}\right)$, median $(\mathrm{IQR})$ & $44(20-59.3)$ \\
\hline PB Blasts $(\%)$, mean \pm SD & $62.5 \pm 22.8$ \\
\hline BM blasts (\%), mean \pm SD & $93.4 \pm 8.5$ \\
\hline $\mathrm{LDH}(\mathrm{IU} / \mathrm{dL})$, mean $\pm \mathrm{SD}$ & $879.7 \pm 411.4$ \\
\hline NG2\% expression, mean (range) & $16.1(2.1-34)$ \\
\hline Positive NG2, n (\%) & $14(31.8)$ \\
\hline $\begin{array}{l}\text { 11q23 Chromosomal aberration } \\
\text { 11q23 break apart (MLL-r), n (\%) }\end{array}$ & $\begin{array}{l}16(36.4) \\
1(2.3)\end{array}$ \\
\hline
\end{tabular}

CNS: central nervous system, WBC: white blood cell count, PB: peripheral blood, BM: bone marrow, LDH: lactate dehydrogenase, NG2: chondroitin sulfate proteoglycan neuron-glial antigen 2, MLL-r: mixed lineage leukemia gene rearrangement.

Table 2. Demographic, clinical and laboratory data among patients with NG2 expression and MLL gene rearrangement

\begin{tabular}{|c|c|c|c|c|c|c|}
\hline Variable & $\begin{array}{l}\text { Positive } \\
\text { MLL-r } \\
\mathrm{n}=16\end{array}$ & $\begin{array}{l}\text { Negative } \\
\text { MLL-r } \\
\mathrm{n}=28\end{array}$ & $P$ & $\begin{array}{l}\text { positive NG2 } \\
\mathrm{n}=14\end{array}$ & $\begin{array}{l}\text { negative NG2 } \\
\mathrm{n}=30\end{array}$ & $\mathrm{P}$ \\
\hline Age (years), median (IQR) & $2.8(1-8)$ & $3.5(2.6-7.5)$ & 0.125 & $4(1-8)$ & $3(2.25-8)$ & 0.221 \\
\hline Males, $\mathrm{n}(\%)$ & $10(62.5)$ & $16(57.1)$ & 0.727 & $6(42.9)$ & $20(66.7)$ & 0.134 \\
\hline Hepatomegaly, n (\%) & $12(75)$ & $18(64.2)$ & 0.462 & $14(100)$ & $16(53.3)$ & 0.002 \\
\hline Splenomegaly, n (\%) & $14(87.5)$ & $20(71.4)$ & 0.221 & $14(100)$ & $20(66.7)$ & 0.014 \\
\hline Lymphadenopathy, n (\%) & $14(87.5)$ & $20(71.4)$ & 0.221 & $12(85.7)$ & $22(73.7)$ & 0.361 \\
\hline CNS infiltration, $\mathrm{n}(\%)$ & $4(25)$ & $0(0)$ & 0.005 & $4(28.6)$ & $0(0)$ & 0.002 \\
\hline WBC $\left(\mathrm{X} 10^{9} / \mathrm{L}\right)$, median $(\mathrm{IQR})$ & $70.5(51.8-96.2)$ & $10.4(4.6-14.7)$ & $<0.001$ & $67.7(32-79.4)$ & $6.5(5.9-7.9)$ & $<0.001$ \\
\hline Hemoglobin $(\mathrm{gm} / \mathrm{dL})$, mean $\pm \mathrm{SD}$ & $7.5 \pm 1.6$ & $6.7 \pm 1.5$ & 0.110 & $7.6 \pm 1.8$ & $6.7 \pm 1.5$ & 0.102 \\
\hline Platelets $\left(\mathrm{X} 10^{9} / \mathrm{L}\right)$, median $(\mathrm{IQR})$ & $55(15-101)$ & $41.5(20-50)$ & 0.111 & $50(10-60)$ & $43(20-57)$ & 0.301 \\
\hline Peripheral blast (\%), mean \pm SD & $67 \pm 17.9$ & $61 \pm 24.7$ & 0.399 & $88.5 \pm 17.1$ & $94.9 \pm 2.2$ & 0.056 \\
\hline BM blasts $(\%)$, mean \pm SD & $90.1 \pm 16.3$ & $94.6 \pm 2.04$ & 0.156 & $60.7 \pm 17.4$ & $63 \pm 24.5$ & 0.752 \\
\hline LDH (IU/dL), mean \pm SD & $1285 \pm 409.01$ & $734 \pm 308.3$ & $<0.001$ & $1057.3 \pm 494.7$ & $825.5 \pm 378.5$ & 0.099 \\
\hline Positive NG2, n (\%) & $12(75)$ & $1(3.6)$ & $<0.001$ & - & - & \\
\hline NG2 $(\%)$, mean \pm SD & $24.3 \pm 12.6$ & $11.4 \pm 5.4$ & $<0.001$ & $28.9 \pm 9$ & $10.1 \pm 4.4$ & $<0.001$ \\
\hline $\begin{array}{l}\text { 11q23 chromosomal aberration } \\
\text { Positive MLL-r, } \mathrm{n}(\%) \\
\text { MLL amplification, } \mathrm{n}(\%)\end{array}$ & 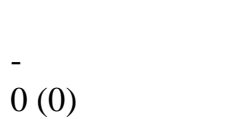 & $\overline{1}-\overline{1}$ & 0.444 & $\begin{array}{l}12(85.7) \\
1(7.1)\end{array}$ & $\begin{array}{l}2(13.3) \\
0(0)\end{array}$ & $\begin{array}{l}<0.001 \\
0.139\end{array}$ \\
\hline
\end{tabular}

CNS: central nervous system, WBC: white blood cell count, PB: peripheral blood, BM: bone marrow, LDH: lactate dehydrogenase, NG2: chondroitin sulfate proteoglycan neuron-glial antigen 2, MLL-r: mixed lineage leukemia gene rearrangement. 


\section{Discussion}

The presence of 11q23 chromosomal aberrations with alteration of MLL gene is generally recognized as an unfavorable prognostic characteristic of some forms of ALL ${ }^{[18]}$. MLL gene translocations result in a chimeric fusion protein in which the $\mathrm{N}$-terminal portion of the MLL gene is fused to the C-terminal portion of the gene fusion partners. These fusion genes may alter the normal cellular proliferation and differentiation processes, favoring leukemogenesis [2,19].

We measured the surface marker NG2 by flow cytomery to evaluate its usefulness as a rapid and less expensive method for early recognition of MLL-r which could help in making early therapeutic decisions in this group of patients with dismal prognosis. The detection of 11q23 aberration was carried out successfully on all studied patients samples using FISH technique, 28 patients were negative for MLL-r, however one case showed three copies of MLL. Positive MLL-r was detected in $16(36.4 \%)$ patients including 6 infants $(37.5 \%)$, and $10(62.5 \%)$ children. Our results revealed the presence of MLL-r in $75 \%$ of studied infants (6 out of 8). Other studies reported MLL-r among infants ( $\leq 12$ months) with B-cell precursor ALL ranging from 40 up to $73.3 \%{ }^{[14,20]}$. ALL with MLL gene rearrangement is the most common leukemia in infants <1year of age accounting for approximately $50 \%$ of cases, while it is less common in older children and increases with age into adulthood (5-6\% of cases) ${ }^{[21]}$.

In the present study, NG2 positivity was detected in $14(31.8 \%)$ of studied ALL patients. A positive correlation was found between NG2 expression by flow cytometry and MLL-r by FISH, where 12 (85.7\%) of NG2 positive patients had MLL-r by FISH, whilst only 2 (12.5\%) MLL-r patients were NG2 negative. ROC curve analysis revealed that NG2 \% expression level $\geq 18.6$ can predict the presence of MLL-r with high specificity and accuracy.

Association between NG2 expression and MLL-r was detected by other studies, Schwartz et al. ${ }^{[22]}$ identified NG2 positivity in $89.4 \%$ of MLL positive adult ALL patients. Emerenciano et al. ${ }^{[14]}$ detected NG2 positivity in 20 out of 27 (74\%) of MLL-AFF1 positive AML patients and in 8 out of 17 (47\%) ALL patients with MLL-r other than MLL-AFF1, collectively they detected NG2 positivity in 28 out of $44(63.6 \%)$ acute leukemia patients with MLL-r.

In the current study, one of the remaining two NG2 positive cases without MLL-r showed three yellow signals indicating MLL amplification that could be either due to trisomy of chromosome 11 or partial tandem duplication (PTD) of MLL which can be detected by RT-PCR.

CNS infiltration was found in 4 patients representing $25 \%$ of MLL-r positive patients, and $28.6 \%$ of $\mathrm{NG} 2+$ which was in agreement with Kosaka et al. ${ }^{[23]}$ who reported CNS involvement in $10(24.4 \%)$ out of 41 MLL positive patients. In addition, Marchesi et al. ${ }^{[2]}$ reported that the presence of $\mathrm{t}(4 ; 11)$ (q21;q23) with expression of the fusion gene MLL-AF4 characterizes a subset of ALL with frequent CNS involvement, with a poor clinical outcome both in infants and in adults.

In the present study, we found that $83.3 \%$ (10 out of 12) of $\mathrm{NG} 2+$ patients presented with leukocytosis $>50 \times 10^{9} / \mathrm{L}$. Likewise, $75 \%$ (12 out of 16 patients) of MLL positive patients presented with $\mathrm{WBC}>50 \times 10^{9} / \mathrm{L}$, and $25 \%$ had $\mathrm{WBC}>$ $100 \times 10^{9} / \mathrm{L}$. In agreement with our findings, Emerenciano et al. ${ }^{[14]}$ reported that $45(75 \%)$ of their studied ALL cases had $\mathrm{WBC} \geq 50 \times 10^{9} / \mathrm{L}$, while Kosaka et al. ${ }^{[23]}$ reported a higher incidence of leukocytosis where 24 (58.3\%) patients had $\mathrm{WBC} \geq 100 \times 10^{9} / \mathrm{L}$.

The association between NG2 expression in this study and the poor prognostic factors; hyperleucoytosis, CNS infiltration, and MLL-r, indicates that NG2 expression could identify a subgroup of ALL patients with poor prognosis. Further longitudinal studies including larger number of patients with extended follow-up may provide additional information. 
In conclusion, immunophenotypic analysis of NG2 expression with a cutoff value $\geq 18.6 \%$ allows the identification and prediction of MLL-r, with high specificity and accuracy suggesting that flow cytometry is a reliable, cost-effective and rapid tool for detection of MLL-r.

Conflict of Interest Statement: Nothing to declare.

\section{Reference}

1. Pui $\mathrm{CH}$, Robison LL, Look AT. Acute lymphoblastic leukaemia. Lancet 2008;371:1030-43.

2. Marchesi E, Girardi K, Avvisati G. Pathogenetic, clinical, and prognostic features of adult $(4 ; 11)(\mathrm{q} 21 ; \mathrm{q} 23) / \mathrm{MLL}-$ AF4 positive B-cell acute lymphoblastic leukemia. Adv Hematol 2011;2011:621-7.

3. Wuchter C, Harbott J, Schoch C, Schnittger S, Borkhardt A, Karawajew L, Ratei R, Ruppert V, Haferlach T, Creutzig U, Dörken B, Ludwig WD. Detection of acute leukemia cells with mixed lineage leukemia (MLL) gene rearrangements by flow cytometry using monoclonal antibody NG2. Leukemia 2000;14:1232-8.

4. Meyer C, Kowarz E, Hofmann J, Renneville A, Zuna J, Trka J, Ben Abdelali R, Macintyre E, De Braekeleer E, De Braekeleer M, Delabesse E. New insights to the MLL recombinome of acute leukemias. Leukemia 2009;23:1490-9.

5. Burmeister $T$, Meyer C, Schwartz S, Hofmann J, Molkentin M, Kowarz E, Schneider B, Raff T, Reinhardt R, Gökbuget N, Hoelzer D. The MLL recombinome of adult CD10-negative Bcell precursor acute lymphoblastic leukemia results from the GMALL study group. Blood 2009; 113:4011-5.

6. Pieters R, Schrappe M, De Lorenzo P, Hann I, De Rossi G, Felice M, Hovi L, LeBlanc T, Szczepanski T, Ferster A, Janka G. A treatment protocol for infants younger than 1 year with acute lymphoblastic leukaemia (Interfant-99): an observational study and a multicentre randomized trial. Lancet 2007;370:240-50

7. van der Linden $\mathrm{MH}$, Valsecchi $\mathrm{MG}$, De Lorenzo P, Möricke A, Janka G, Leblanc TM, Felice M, Biondi A, Campbell M, Hann I, Rubnitz JE. Outcome of congenital acute lymphoblastic leukemia treated on the Interfant-99 protocol. Blood 2009;114:3764-8.

8. Tomizawa D, Koh K, Sato T, Kinukawa N, Morimoto A, Isoyama K, Kosaka Y, Oda T, Oda M, Hayashi Y, Eguchi M. Outcome of risk-based therapy for infant acute lymphoblastic leukemia with or without an MLL gene rearrangement, with emphasis on late effects: a final report of two consecutive studies, MLL96 and MLL98, of the Japan Infant Leukemia Study Group. Leukemia 2007;21:2258-63.

9. Behm FG, Smith FO, Raimondi SC, Pui $\mathrm{CH}$, Bernstein ID. Human homologue of the rat chondroitin sulfate proteoglycan, NG2, detected by monoclonal antibody 7 . 1, identifies childhood acute lymphoblastic leukemias with $\mathrm{t}(4 ; 11)(\mathrm{q} 21 ; \mathrm{q} 23)$ or $\mathrm{t}(11 ; 19)(\mathrm{q} 23 ; \mathrm{p} 13)$ and MLL gene rearrangements. Blood 1996;87:1134-9.

10. Hilden JM, Smith FO, Frestedt JL, McGlennen R, Howells WB, Sorensen PH, Arthur DC, Woods WG, Buckley J, Bernstein ID, Kersey JH. MLL gene rearrangement, cytogenetic 11q23 abnormalities, and expression of the NG2 molecule in infant acute myeloid leukemia. Blood 1997;89:3801-5.

11. Smith FO, Rauch C, Williams DE, March CJ, Arthur D, Hilden J, Lampkin BC, Buckley JD, Buckley CV, Woods WG, Dinndorf PA. The human homologue of rat NG2, a chondroitin sulfate proteoglycan, is not expressed on the cell surface of normal hematopoietic cells but is expressed by acute myeloid leukemia 
blasts from poor-prognosis patients with abnormalities of chromosome band 11q23. Blood 1996;87:1123-33.

12. Wuchter C, Harbott J, Schoch C, Schnittger S, Borkhardt A, Karawajew L, Ratei R, Ruppert V, Haferlach T, Creutzig U, Dorken B. Detection of acute leukemia cells with mixed lineage leukemia (MLL) gene rearrangements by flow cytometry using monoclonal antibody 7.1. Leukemia 2000;14:1232-8.

13. Bueno C, Montes R, Martin L, Prat I, Hernandez MC, Orfao A, Menendez P. NG2 antigen is expressed in CD34+ HPCs and plasmacytoid dendritic cell precursors: is NG2 expression in leukemia dependent on the target cell where leukemogenesis is triggered? Leukemia 2008;22:1475-8.

14. Emerenciano M, Renaud G, Sant'Ana M, Barbieria C, Passetti F and Pombo-deOliveira M. Challenges in the use of NG2 antigen as a marker to predict MLL rearrangements in multi-center studies. Leukemia Research 2011;35: 1001-1007.

15. Bueno C, Montes R, Catalina P, Rodriguez $\mathrm{R}$, Menendez P. Insights into the cellular origin and etiology of the infant pro-B acute lymphoblastic leukemia with MLLAF4 rearrangement. Leukemia 2011;25:400-10.

16. Vardiman JW, Thiele J, Arber DA, Brunning RD, Borowitz MJ, Porwit A, Harris NL, Le Beau MM, HellströmLindberg E, Tefferi A, Bloomfield CD. The 2008 revision of the World Health Organization (WHO) classification of myeloid neoplasms and acute leukemia: rationale and important changes. Blood. 2009;114:937-951.

17. Hopman AH, Voorter CE, Ramaekers FC. Detection of genomic changes in cancer by in situ hybridization. Mol Biol Rep 1994;19:31-44.
18. Meyer C, Schneider B, Jackob S. The MLL recombinome of acute leukemias. Leuk 2006;20:777-784.

19. Ayton P M, Cleary ML. Molecular mechanism of leukemogenesis mediated by MLL fusion proteins. Oncogen 2001;20:5695-5707.

20. Sam TN, Kersey JH, Linabery AM, Johnson KJ, Heerema NA, Hilden JM, Davies SM, Reaman GH, Ross JA. MLL gene rearrangements in infant leukemia vary with age at diagnosis and selected demographic factors: a Children's Oncology Group (COG) study. Pediatric blood and cancer 2012;58: 836-839.

21. Borwitz MJ, Chan JK. B lymphoblastic leukemia/ lymphoma with recurrent genetic abnormalities. In: WHO classification of tumors of hematopoietic and lymphatic tissue. Steven H, Elias C, Nancy L, ELanta S J, Stetano A, Harald S, Jurgen $\mathrm{T}$ and James $\mathrm{W}$ (eds). $4^{\text {th }}$ edition. 2008. Chapter 9. P.P: 171-175. International Agency for Research on Cancer. Lyon, France.

22. Schwartz S, Rieder H, Schl"ager B, Burmeister T, Fischer L, Thiel E. Expression of the human homologue of rat NG2 in adult acute lymphoblastic leukemia: close association with MLL rearrangement and a CD10(-)/CD24()/CD65s(+)/ CD15(+) B-cell phenotype. Leukemia 2003;17:1589-1595.

23. Kosaka Y, Koh K, Kinukawa N, Wakazono Y, Isoyama K, Oda T, Hayashi Y, Ohta S, Moritake H, Oda M, Nagatoshi $\mathrm{Y}$, Kigasawa $\mathrm{H}$, Ishida $\mathrm{Y}$, Ohara A, Hanada R, Sako M, Sato T, Mizutani S, Horibe K, Ishii E. Infant acute lymphoblastic leukemia with MLL gene rearrangements: outcome following intensive chemotherapy and hematopoietic stem cell transplantation. Blood 2004;104:3527-3534. 